\title{
Artistic Freedom against Moral Responsibilities: An Appraisal of Aesthetics against Ethics
}

\author{
$\sim$ Gaurav Bhattarai $^{1}$
}

\section{Abstract}

How the hate speech should be separated from the free speech and why the blasphemous laws should be banned to shield free thought and freedom of expression from any danger or damage? This article examines the argument that whether blasphemous art should be publicly displayed, and if yes, in what manner artist are free and to what extent they should be responsible while exercising their artistic freedom. The write-up argues against those who say blasphemy is an offence, an attack on religion and sacred, to aver that blasphemy shouldn't be understood merely on the moral and ethical lines, but through the contextual and philosophical understandings of the issue. Particularly, this write-up criticizes the blasphemy laws, including fatwas and death threats issued against two writers--Salman Rushdie and Taslima Nasrin. Finally, the this paper discusses how the notion of blasphemy itself is the product of misunderstanding and misreading the free speech as the hate speech. The article concludes that the line between aesthetics and ethics, between art and religion, should be drawn only by the rationalistic judgment of the contextual issues and for that artist's intention should be realized at first, before colligating it with the religious matters, ethical issues and falsely apprehending freedom of thought as a sacrilege and profanation.

Key Words: Blasphemy, Free Speech, Hate Speech, Rushdie, Nasrin

Sometimes a writer is not appraised for what he wrote. In adverse circumstances, serious and dedicated writers and artists have to confront fusses and hassles against what they have penned. Most often the thunderclap fall on them, when their writings happen to scrutinize the issues which are commonly considered as sacred and sanctified. They are scorned and disdained by the believers citing the religious standpoint that sacred cannot be studied and analyzed. Contrary to those who reckon that there can be nothing beyond sacred and going beyond it is sinful, writers have always dared to challenge the believer's partipris argument by invoking the rationalistic judgments to study religion as a text. But such daring when provokes fundamentalists and fanatics, death threats

1 As one of the member of the Research Department and Assistant Professor of Koteshwor Multiple Campus (KMC), Mr. Gaurav Bhattarai is International Relations Scholar. His areas of interest are Terrorism, Fundamentalism, Democratization, Trilaterialism, Foreign Policy of Great and Emerging Powers, and Small States. He teaches World Political Affairs and International Organizations to the Students of International Relations at Tribhuvan University, Kathmandu, Nepal. 
and fatwas are issued against writers, usually by the authorities of such societies where role of religion is pivotal for political power. Most probably, it is the reason that the penal codes for blasphemy tend to be severe and cold.

If literature is ordinarily understood as the purposeful reflection of the world, to what extent then writers are free to share their cerebrations, memories and belles-lettres to the outside world, and to what degree they should be responsible? It is always a pertaining moral question and will remain so over generation and generation. Because, to be the voice of the generation is not an easy task. Writers sometimes have to be the subject of unusual vicissitudes just because of what they wrote out of their experiences and memories. The case of two writers, Salman Rushdie and Taslima Nasrin exemplify the case better. Both of them belong to Indian sub-continent. Both of them are Muslims, but Muslim world is antipathetical to them for what they wrote. Precisely, their writings have been despised as blasphemous. Albeit Rushdie's The Satanic Verses is his experience "with the nature of revelation" (24, Joseph Anton) and Taslima Nasrin's Lajja records man's inhumanity to man in the name of religion, both of them have been accused of being against Islam, the Prophet and the Quran. They even received death threats from Muslim extremists.

It is said that when one is blinded by religion, they fail to see and appreciate the sheer art. It was not a sentence issued by any court or which had any jurisdiction over them. Their crime was just that they wrote novels out of their experiences and memories. Memory and experience play a pivotal role in a writer's life. He writes on paper what he sees, feels and experiences in the social world. Monte Wildhorn (Played by Morgan Freeman) correctly says in the movie, The Magic of Belle Isle, to a child," to narrate a good story you don't have to go outside of this globe". Yes, there are writers who do on papers what they couldn't do in the real world. Amitav Ghosh's in his masterpiece, The Ghosts of Mrs Gandhi, has prioritized the inevitability of both the artistic freedom and artistic responsibilities. It is not that Nasrin and Rushdie paid no heed to the latter part. Writers are free to play with words but commitment in literature also matters. Ghosh says: "How was I to write about what I had seen without reducing it to a mere spectacle? In such incendiary circumstances, words cost lives and it is only appropriate that those who deal in words should pay scrupulous attention to what they say"(201). For Ghosh, writers ought to be principled. They need to ingest extreme care and great effort, with an acute sense of right and wrong. Artistic composition is not an easy undertaking. A writer has to comprehend the objective world correctly and concurrently express his images clearly through his choice of words.

Rushdie says he actually made "an artistic engagement with the phenomenon of revelation; an engagement from the point of view of an unbeliever, certainly, but a proper one nonetheless. How could that be thought offensive?" (Joseph Anton, 74). 
Similarly, Nasrin says she wrote about the attacks on Hindus in Bangladesh after the destruction of the Ayodhya mosque in India by Hindu extremists on December 6, 1992. But Lajja was banned by Bangladesh government in 1993 saying that "it was disturbing the communal peace" and even fatwa was issued against her by Muslim fundamentalists. Rushdie was also sentenced to death by Ayatollah Khomeini, the Iranian religious leader of the Shiites on the Valentine's Day of 1989.

For supposedly sacrilegious portrayal of the Islam and prophet Muhammad, fatwa was issued against them, which actually have birthed a piercing question: does artistic freedom exist? It is more intemperate even to presume that renowned writers like Rushdie and Nasrin have not understood the relationship between artistic license and social responsibility.

Jean Paul Sartre in Why We Write has realized the importance of social responsibilities by emphasizing on the importance of readers. For Sartre, a work of art finds its completion only after it finds its readers. He argues:

One of the chief motives of artistic creation is certainly the need of feeling that we are in relationship to the world...it is not true that one writes for oneself...it is the joint effort of author and reader and reader which brings upon the scene that concrete and imaginary object which is the work of the mind. There is no art except for and by others...the creation can find its fulfillment only in reading (28-33).

Rushdie and Nasrin must have understood that they will be read by millions. Actually they wrote for the world to let them know where the wonderment (in case of Rushdie) regarding fantasy and religion has taken him, and where the observation of atrocious situation (in case of Nasrin) has taken her. Somewhere in between, they both reread the historical and contemporary practices in Islam religion and in that course they have also divulged the deformities in Islam (coming to the issue of violence and position of women in Lajja) as Martin Luther did in Christianity.

A writer always portrays the society he sees it, and the way he wishes it to be. Because, a writer is always the product of the society he lives in. "A book is a version of the world. If you do not like it, ignore it; or offer your own version in return ". (Joseph Anton, 1). G. V. Plekhnov in his work, Art and Social life has made this idea (artworks have always social references) clearer:

I consider, however, that Art begins at the point where man, evokes within himself anew feelings and thoughts experienced by him under the influence of his environment and gives a certain expression to them in image. It goes without saying, that in the vast majority of instances he does this in order to convey to other people the thoughts and feelings he has recalled. Art is a social phenomenon (20). Rushdie and Nasrin wrote 
what they saw with their eyes and what they felt in their mind and heart about their observation and experience of Islam, and they wanted rest of the world to know about their thoughts and feelings. For that purpose, they chose fiction, which zealots and fanatics misinterpreted as blasphemous and misrepresented as the product of hate speech.

Art, in the age of fundamentalism has to always undergo assorted difficulties. Even Longinus in the First Century A.D. understood that "the decline of democratic government has probably been a reason for the decline in sublimity among writers ( 75 , Critical Theory Since Plato). In his chef-d'oeuvre, On the Sublime, Longinus has said that sublimity cannot be actually defined but has mentioned the five elements that help create elevated language. The sublime author must have the "power of forming great conceptions"(elevation of mind) or the "echo of great soul". The second quality he states is "vehement and inspired passion". The last three are: figures of speech, noble diction and dignified composition (75, Critical Theory Since Plato). The final three can be deemed as the features of poem.

It was actually the decline of democratic government in Rushdie and Nasrin's cases as well. Under a despotic rule, pen of novelists, poets, playwrights, historians, essayists, biographers, translators won't be mightier anymore, and when they won't be free to write and express, their aesthetic responsibilities would be a mere ironical stance.

The Satanic verses and Lajja have been badged as blasphemous art by fundamentalist organizations. To term any kind of art as offensive and prohibit viewing it as blasphemous, is the result of the tension between what is worthy to call sacred and what is seen as a departure from religious faith. On Art and Literature, even the Chinese communist leader (1893-1976)Mao Tsetung has said that the true, the good and the beautiful always exist in contrast to the false, the evil, and the ugly and develop in struggle with the latter. In the words of Russian writer Maksim Gorky, it refers to active romanticism, which actually " strives to strengthen man's will to live and raise him up against the life around him, against nay yoke it would impose"( 32-33, On Literature). If blasphemous references are the result of the constant struggle between what is called sacred and what is seen as profane, to Gorky sacred means putting an end to all the negative traits. Gorky says:

If there is need to speak of the sacred, then $i$ will say that the only thing $i$ hold sacred is man's dissatisfaction with himself, his striving to become better than he is; I also hold sacred his hatred of all the rubbish that clutters up life and which he himself was brought into being; his desire to put an end to envy, greed, crime, disease, wars, and all enmity among people in the world (67). If we take Gorky's understanding of' sacred' into consideration, Rushdie and Nasrin have actually wrote of sacred ways 
to reforming any society bewitched by religious superstitions, fallacies concerned with faith, belief and creed, religious persecution, racial extermination and communalism, which have eventually riled the extremists, fundamentalist and hate breeders against dissemination of free thoughts and free speech.

Rushdie and Nasrin used literature as their tool to combat the social, religious and mythical deformities, as art is that product of human creativity which elevates man from a disjointed and fragmented state into an integrated and unified being, and helps him to comprehend reality in the better light.

To Saint Augustine( 354-430) however, literature comes out of signs and signs are important because it points to something else, and that something else is ultimately the Trinity of Father, Son and Holy Ghost. Pleasure comes only when signs are used in the movement of signification towards God, not in the aesthetic surface of the sign. It is this view which leads to the idea of allegory in the medieval criticism. The idea of Augustine was reinforced by Saint Thomas Aquinas (1225-1274). For Aquinas, the world itself is a symbol which can be interpreted as the work of God. Aquinas applied it to Scripture but Dante Alighieri (1265-1321) extended it to the interpretation of secular writing as well. Henry Reynolds (1627-1632) also defended allegorical content and fended for ancient writers to modern ones. In Mythomystes, he is critical of those moderns who learn only style, phrase, and manner of expression from the ancients. He shows his interest in " secreter mysteries, and absurdities of most high divinity, hidden and concealed under the bark and rude cover of the words"' 185, Critical Theory Since Plato). But, David Hume (1711-1776) gives priority to 'taste'. The literary taste of a young man of twenty won't be similar to that of a man of fifty and his again from that of seventy. One may be pleased by pleased by the allegory; another may be pleased with sublime and the third with the social realism. Some sees the texts of Rushdie and Narsim as edifying and others may probably find it reprehensible, which is only the matter of taste. Some may locate the plethora of common sentiments of human nature in both the texts while others at variance may just offend The Satanic Verses and Lajja arguing that they are foul-mouthed and blasphemous. Edmund Burke (17291797), however, finds taste and judgment intertwined in all human activity. He believes that taste improves as judgment improves through increased knowledge, attention and exercise. But R.P. Blackmur (1904-1965) views that a literary text is always distinct from its reader's taste. For Blackmur, a work of art shouldn't be reduced to a doctrine, but should be understood as 'the thing in itself from its own point of view'. A text is autonomous and has an ontological status of its own for the New Critics like Blackmur. W.K. Wimsatt(1907-1975) and Monroe C. Beardsley ( 1915-1985) even discussed two fallacies: the intentional fallacy and the affective fallacy. By intentional fallacy, Wimsatt and Beardsley mean confusion between the text and its origins (author's biography). 
Affective fallacy, however, is confusion between the poem and its results (the affection that text imparts into its readers). Wimsatt and Beardsley believe that readers must dismiss the author's biography, and purging of emotional tensions while interpreting a text. New Criticism says Rushdie's Midnight Children or Nasrin's any other texts besides Lajja shouldn't be read in the light that a fatwa was issued against them. It also advises critics not to pay attention to the effects of the books on the reader. New Criticism argues that characters in the novels shouldn't be confused with the author's voice. But, Northrop Frye (1912-1991) defines literature as a "disembodied use of words". Prioritizing allegory, Fry insists that in all literary writings, meaning is always inward, only the technique is outward. To E.D.Hirsch, Jr, however, the meaning of the text is always what the author meant for the meaning of the text may vary from age to age. A text doesn't derive meaning from the reader but from the speaking subject. But, Roland Barthes (1915-1980) in The Death of the Author privileges the text over the author, which actually is the deconstructive view of the author, and endorses the Heideggerian idea that language speaks man. What is an Author by Michel Foucault (1926-1984) also treads same path. In Truth and Power, Foucault studied the circulation of power through society and literary texts that are part of it. Foucault says, "Truth is linked in a circular relation with systems of power, which produce and sustain it, and to effects of power which it induces and which extend it"(1145, Critical Theory Since Plato). Similarly, Edward W. Said, in The World, the Text and the Critic, argues against Derridean deconstruction, that texts should be regarded as speech. All texts are worldly, says Said and the text's voice may dominate some other voices like the unequal relation of colonizers and the colonized. Said views the text in political light and is concerned with historical situations.

Rushdie and Nasrin wrote about events inside the history, which is of course not an easy chore. But they did that with a true connoisseur's ability, not in sputter. Rushdie reconstructed the origin of the Islam religion in a meta-fictional manner inside the head of a schizotypal personality, and Nasrin wrote about the atrocities and malevolence practised by Bangladeshi Muslims against Hindu minorities. Unlike science, history involves the issues of morality and religion, the issues on which their novels revolve around, and in tandem the grounds on which charges of blasphemy and fatwa were issued against them. In the penal codes of many countries, despite their secular and democratic beliefs, blasphemy laws still exist to prosecute writers and artists in case of religious crimes. In addition to Islamic states, Austria (Articles 188, 189 of the penal code), Finland (Section 10 of chapter 17 of the penal code), The Netherlands (Article 147 of the penal code), Spain (Article 525 of the penal code), Switzerland (Article 261 of the penal code), Denmark (Paragraph 140 of the penal code) promotes persecutions against blasphemy, as a result of which freedom of expression, and autonomy of art are at stake. 
Blasphemy laws are the result of misconceiving free speech as the hate speech. Actually there is only freedom of speech, and the interminable debate between what is free speech and what is hate speech could be resolved only by the contextual understanding of the issue by developing critical insights, tolerance, imagination and sensitivity, and above all treading on aesthetic judgment unrestricted by ethical values. Literature which has been always praised for its means to provide relief even in adverse circumstances is always endowed with the status of being free; the power to speak and act sans externally imposed restraints. Literature itself is an answer to the instinct aroused to destroy and kill, the instinct which is gripped by zero tolerance for plurality and is never reluctant to practice bigotry and hurt those who come up with different opinions and free thinking. Man has always been the storytelling animal. Man is the only creature on earth who constructs stories to understand himself and his relation to others. But why his birthright--to tell story-- is being snatched in the name of sacred? Why his words are taken as crimes if he dares to sharpen his learning from the fetters of theology, for the sake of human reason and against unreasoning belief and blind submission. If morality is a considered as the rationalized attitude to justify the blasphemy, morality shouldn't be confused with the blind belief, and if morality or ethics plays such an important role to define whether an artwork is blasphemous or not, the idea of moral courage also shouldn't be brushed aside. The moral courage to differentiate what is actually a hate speech and what is free speech. But such differentiation is feasible only through the rationalistic understanding of the contextual issues.

\section{Of Ethics and Aesthetics}

The interaction or overlap of ethics and aesthetics has always drawn the attention of scholars and academicians over diverse range of issues. But, while discussing the issue of blasphemy, it is not just an 'overlap' or 'interaction' but a conflict, wherein believers defend their ethical and moral standpoint and artists/writers fend for artistic importance and aesthetic improvement, even in the sacred objects. The lack of ethical and moral stances, as per the expectation of moralizer, in any artworks, is always detested and contemned by fundamentalists and rabids as sacrilegious, profane and blasphemous.

Unlike sacrilege, which refers to the violation of sacred things, blasphemy means speaking against God or saying anything against sacred or ridiculing things attached to God or which are at least held as sacred. According to New Oxford Dictionary of English, edited by Judy Pearsall, blasphemy is not doctrinal like heresy but chiefly textual, of more linguistic nature rather than ideological nature. It is "the action or offense of speaking sacrilegiously about God or sacred things; profane talk." The Catholic Encyclopedia defines blasphemy as a mortal sin, the gravest that may be committed against religion. Blasphemies are understood are the worst of crimes since 
antiquity. Ancient Greek sculptor (circa 500-432 BC) Phidias was prosecuted for carving a figure of himself on the shield of the statue of Athena (Goddess of wisdom in Greek mythology). In the Middle Age, Thomas Aquinas said in Summa Theologica $2: 2$, q. 13, that victimizing God is a greater threat to common god than victimizing people. Comparing murder and blasphemy as regards to the objects of sin, Aquinas says that blasphemy is a sin committed directly against God, and thus graver than murder. But, if we compare them in respect of the harm brought by them, murder is the graver sin, because murder does more harm to society, than blasphemy does to God. Jewish and Christian Scriptures have also opposed blasphemy. Islam deplores words and actions of infidelity (kalimat al-kufr), denigration (istikhfaf), contempt (ihanah), or scorn (haqarah). But the religious and social punishments and sentences in Islam and Christianity are different and have undergone dramatic changes. Since the concept of blasphemy is closely linked both to religion and with language, is blasphemous language always reprehensible giving birth to clashes, conflicts and violence? To answer this question, we first need to make a multidimensional understanding of what blasphemy actually is. At first, we need to understand the relation between religion, language, ideology and tolerance; how aesthetics intersects with ethics and results into a conflict between art and religion.

The debated issue of blasphemy has been approached from historical, ethical, literary, aesthetic and secular ways. According to Anthony Fisher and Hayden Ramsayin Of Art and Blasphemy, various disciplines approach blasphemy differently. An anthropologist may study it as an example of taboo and taboo-breaking; a historian may read it in a line of religious persecutions, artistic provocations or juridical evasion; the jurist may understand it as the gradual separation of church and state and the removal of legal remedies from church agencies; sociologist may read it as an example of the struggle for authority between rival institutions or between institutions and the general population; the theologian may take it as an evidence of the secularisation of West and the vilification of religion is doctrinaire secular societies; for the art critic, it may be the another victory of philistinism. For philosophers, it raises some important questions about the relationship between art and religion in modern liberal societies. Yet 'blasphemy', 'sacrilege', 'profanation'-- such words may seem archaic and such notions alien today.

Anthony Fisher and Hayden Ramsay also discuss how blasphemy is understood as an offence. To believers, the public display of blasphemous or sacrilegious works is hurtful and shocking as they cannot see their God being trivialized, their sovereign Lord being insulted in the name of art. In any culture or religion profaning a sacred object (like immersing it in urine as in Piss Christ) would be a sacrilege. Publicly displaying the record of such an act by photographing it is a blasphemous act in 
almost any culture, and if the public display is deliberately provocative, this in turn demonstrates disrespect for a particular religion. Can philosophy, art and democracy make any sense to the widespread outrage at offences such as sacrilege and blasphemy? Although Salman Rushdie's The Satanic Verses and Lajja have been considered as blasphemous from theological, legal, sociological, political, and anthropological point of views, a thorough philosophical analysis is still lacking. They wrote fiction and fiction is unrestricted by moralities and moralizers' impositions. Fiction is based on imagination, which itself is a wing to reality. They wrote free speech but unfortunately their free speeches have been misapprehended as hate speech by the hate breeders and religious rabids, for their alleged offensive attack on religion and the idea of sacred.

Fisher and Ramsay examine four philosophical approaches to blasphemy: blasphemy as offence, attack on religion, attack on the sacred, attack on the blasphemer himself. Then, after considering four aspects of art, they offer some thoughts on the conflict between freedom of religion and freedom of artistic expression, and whether 'blasphemous art' is properly regarded as a public offence. In forwarding 'blasphemy as offence' argument, Fisher and Ramsay turn to philosophers, who believe act cannot be understood as morally wrong until they adversely affect the interests of particular group, either by harming them or by causing serious offence. For philosophers, what is wrong with the blasphemy is that it offends others. What to do with the complaints lodged against blasphemy? That they need not view the offensive matter and should go and play or listen to music instead? Believers always want their God be respected and are always ready to complain against the offences which demean those things which they hold most precious to their hearts and souls.

Fisher and Ramsay say blasphemy is not harm or offence to believers but it is a deliberate attack on (the human good of) religion. Beauty and religion, or in other words, aesthetics and spiritual experience are two examples of such goods but they may not be pursued by everyone, and everywhere; and it is not to say that they are the only or most important values. For Fisher and Ramsay, there will always be good reasons to do things in pursuit of art or religion, just as there may not be good reasons to do so. Fisher and Ramsay rightly mention that though art and religion are basic goods to be pursued in morally reasonable ways, it doesn't mean that they will be equally valued by everyone or equally emphasized in their lives. On 'blasphemy as attack on religion', Fisher and Ramsay opine that religion itself is a constructive art, and to sacrilege it means to attack art. They write:

Just as vandalism of art is not a positive moral stance that happens to offend some artists but an act directly aimed against the good of aesthetic experience, so art by sacrilege is not an exercise in creativity that happens to offend the faithful but a direct attack upon religion(147). 
Fisher and Ramsay weigh the spiritual experience against aesthetic experience and call for reverence for them, for the common good even in the modern and secular society. They are of the view that blasphemies impoverish people's participation in religion and radically undermine people's faith and understanding, because the most serious blasphemies constitute attack not only on human values or goods but on the Sacred itself.

Being a Blasphemer, or hater of God, or enemy of the Sacred, is a risk to himself as well. Fisher and Ramsay have elaborated this idea on the topic--'Blasphemy as an attack on blasphemer'. Fisher and Ramsay think that the offenders of believers or the enemies of faith are usually risked by spiritual isolation, alienation, turmoil, meaninglessness and strange inclinations at the times of trouble. Some may link this idea to the way Rushdie and Nasrin went on hiding after fatwas were issued against them. But, artists have some different story to tell though disciples of Hans-Georg Gadamer (1986) believe that self-interpretation of the artist shouldn't be taken too seriously. Artist of the Andres Serrano's controversial Piss Christ (a photograph of a crucifix immersed in the artist's urine) said to ABC Radio National in 1997:

"I started that work as an attempt to reduce and simplify a lot of the ideas and images that I had been doing up until that time. I didn't do it to be provocative; I did it because damn, the colors would look good. I just feel like what I do has the simplest answers, but they aren't good enough. People want more of a story and I realize I try to give them a story, but sometimes I have to say: look, you're reading too much into this shit really, you know." Though the work caused an offence to Christian communities, which would have responded to the immersion differently if the crucifix had been immersed in some holy water and titled with some sacred words. But the idea-- that a work of art is not blasphemous in itself, but only in the context of its being considered by others-- is commonly raised issue while defending the art-works and the artist of the Andres Serrano's controversial Piss Christ did the same, while talking to the radio.

Is blasphemous art provocative and confronting? Fisher and Ramsay say that artists demand the unshackled right to attack and bother others, but if this happens to them, in the reactionary attack, they are scared, saying that they have fallen prey to intolerance, despotism, and fundamentalism. Now the plight of commoners is that if they stand indifferent to the claims of art, they are called philistine, and if they respond with rage and fury, they are deemed as a member of the mob mashing for blood. Samuel Laeuchli notes "art invites responses, art challenges, and challenge and response can bring about violence "(63). If blasphemous art is deliberately provocative, the artists shouldn't get surprised by the effects it provokes. 
To expand their arguments against defenses of blasphemous art as beautiful, provocative, devout, and distinct from legitimate religious concerns, Anthony Fisher and Hayden Ramsay say that the goal of the artist of Andres Serrano's controversial Piss Christ (as the artist later asserted) along had been to display Christ in pain, suffering and humiliation so that he could augment the devotion of his fellow Christians by helping them identify better with Christ in Pain. Some of the artist's defenders interpreted it as Jesus losing control of his bladder in the crucifixion and the Roman soldiers probably pissed on him. But the question Fisher and Ramsay bring up is, do the sacred and revered really work in this way? The artist created a "modern Christ, a terrified Christ, a humiliated Christ, an exultant Christ "(157) by adding 'grime' to sacramental images and religious symbols. For Fisher and Ramsay, blasphemy is wrong in itself, whether the intention of the artist is counted or not. They write:

Even if it were the case that blasphemy might be used by an artist with some good goal in mind--such as devotion or furthering public debate about the merits or demerits of some particular religion--this does not amount to an argument against the intrinsic wrong of blasphemy(158).

Fisher and Ramsay reckon that if Serrano had love and respect for the crucified Christ, the degree of reverence in the photograph is not more than a 'funny internal felling'. If the work is pious, then what is impious? It seems the line separating aesthetics and ethics is hazy and blurry.

If art and religion are considered as distinct disciplines, why churches or religious communities claim expertise in aesthetics, and arts community take positions on what is blasphemous and sacrilegious? Though distinct, art and religion are not autonomous: there are art works with religious contents and inspirations, and religion is all about "symbol, ritual and display"(159). For Anthony Fisher and Hayden Ramsay, neither art nor religions are properly autonomous of morality. They write:

If the separation of art and religion can be distorting, equally misleading has been the reduction of sacrilege and blasphemy to the sphere of the peculiarly religious (like a dispute over the Trinity, or Whether Christ is God or Prophet), rather than seeing them as the moral categories they primarily are (159). Fisher and Ramsay believe that whether it is religious communities (no aesthetics beyond ethics) or arts community (no ethics beyond aesthetics) should learn to abide themselves by the moral responsibilities. Hence, for them, blasphemy is subject of moral analysis. They come up with an example of what would be the reaction to the prospect of various objects made from skin, bone and other parts of Holocaust victims being put on display in an art gallery? Would we be convinced if curators pay heed only to the artistic merits, even outraging Jews?

Arguing that blasphemous arts have "affects upon self, particular others and the common 
good"(160), Fisher and Ramsay call blasphemy a public offence. In a democratic society, man is always free to speak truth and teach about the religious affairs, but it doesn't mean that he is free to make an opprobrious attack on religious doctrines, in a public place where passer-by may feel offended. Richard Webster (1990) in his Brief History of Blasphemy notes that:

Participants in the debate have again and again talked as though the tradition of free speech is an abstract principle, formulated primarily for the benefit of small elite of intellectuals and artists...there is reluctance to discriminate between the freedom to impart information and the freedom to insult, offend or abuse(572).

Webster is hinting at the counterbalance of the freedom of expression. It should be acknowledged that democracies guarantee not only freedom of expression but also freedom of religion. Webster says, such 'reluctancy' demeans the liberal tradition of free expression of ideas and opinions, because they are stubbornly reluctant to the responsibilities which come with such freedom.

In Blasphemy: Verbal Offences Against the Sacred, from Moses to Salman Rushdie (1993) Leonard W. Levy first examines the blasphemies of Socrates, Aristotle, Michael Servetus, Giordano Bruno, George Fox, Jesus, Thomas Pain, William Pen, and others, and then presents details on how throughout the history prosecution for blasphemies were colored with political consideration in the system where the political powers identify themselves with the divine right. Levy asks, "If vengeance belongs to the supernatural governor of life, why invoke the criminal law?" Levy argues that using criminal law to alleviate 'affronted religious feelings, imperils liberty'. In Treason against God: A History of the Offense of Blasphemy (1981), Levy states:

Reasonable people should have learned by now that morality can and does exist without religion, and that Christianity is capable of surviving without penal sanctions. The use of the criminal law to assuage affronted religious feelings imperils liberty. Blasphemy laws ... are reminders that a special legal preference for religion in general, or for Christianity in particular, violates the Constitution. They are reminders too that the feculent odor of persecution for the cause of conscience, which is the basic principle on which blasphemy laws rest, has not yet dissipated ( 133).

Unlike Fisher and Ramsay, who call for moral responsibility in artists, Levy believes that the existence and functioning of morality is not dependent to the continuation of religious values. For him, morality can exist without religion also. The moral ground that Fisher and Ramsay envisaged and what Levy has ideated is different. Levy is worried about the dangers that anti-blasphemy laws posses and saddened by the idea of persecution for the cause of conscience. Blasphemy, according to Levy, not only violates constitution but also indicate the darker side of religion. The English common law, according to Blackstone, defines blasphemy as: "Against the Almighty, by denying his being or providence; or by contumelious reproaches of our saviour Christ. Whither also 
may be referred as profane scoffing at the Holy Scripture, or exposing it to contempt and ridicule...or Christianity is part of the laws of England". In Britain, blasphemy is still a prosecutable offence. But the case of Salman Rushdie raises a question, is blasphemy concerned with promoting unity among religions, or only Christianity is protected? Is Islam protected under the laws of blasphemy? If yes, then Muslim population in the United Kingdom could file a case against Rushdie and punish him under the British law. If not, what are its implications to countries like Great Britain with significant Muslim populations, but no laws to defend their religious feelings. Unlike Rushdie's case, in the year 1979, Denis Lemon, the editor of the Gay News was convicted for printing a poem, The Love that Dares to Speak, describing a Roman soldier fellating the crucified. The House of Lords upheld the conviction. Also in the year, 1989, the government invoked the blasphemy law for suppressing "Visions of Ecstasy," a movie about the 16th-century Saint Teresa of Avila.

If we believe what Omar Abd al-Rahman (currently imprisoned in the United States for his role in the September 11th attacks) said that they had killed Naguib Mahfouz in 1959 for having written Children of Gebelawi, and scrutinizing the case of Rushdie and Nasrin, Muslim fundamentalists and Muslim theologians have demonstrated far more radical view on blasphemy. Muslim's extremist and inhuman stance against blasphemy can be well understood from the open letter to Taslima Nasrin from Salman Rushdie, ensuring latter of his and other writers (Kundera, Mario Vargas Llosa, and Czeslaw Milosz) support. Rushdie wrote: "How sad it must be to believe in a God of blood! What an Islam they have made, these apostles of death, and how important it is to have the courage to dissent from it... You have spoken out about the oppression of the women under Islam, and what you said needed saying." Russell writes how an individual always has to be the victim of state power and principles, and particularity in societies tethered by religious principles or a particular religious belief, an individual seeking reforms and changes have to be the subject of penalization and judgments of conviction. In The Analysis of Mind, Bertrand Russell statements against blasphemy echo Rushdie's voice. Russell writes:

Those who have sufficient power usually imprison or put to death anyone who tries to shake their faith in their own excellence or in that of the universe; it is for this reason that seditious libel and blasphemy have always been, and still are, criminal offences (24). Yes, tolerance is a rare

virtue which a moralizer who wants others to conform to his view, by kneeling down to his power, never possesses, but coercively tries to defend his actions by forwarding blasphemy laws.

Rushdie admits that his rationale was not to write about Islam but to speak about the nature and phenomenon of revelation. But whenever a writer tries to fictionalize a religious issue, he has to be subject of controversy and sometimes even have to confront something fraught with danger like Fatwa. In an interview to NPR's Steve Inskeep, Rushdie says: 
"My purpose was not to write only about Islam; it was to talk about the nature of revelation, and also to suggest that when a big, new idea comes into the world, it must answer two challenges: One is the challenge of how do you behave when you're weak? And the other, how do you behave when you're strong? When you're weak, do you bend, do you compromise? Or are you [unyielding] and firm? And when you're strong - when you're victorious - are you cruel and vengeful, or are you merciful and forgiving? And actually, in my view, the story as it exists in the novel reflects rather well on the new idea of the religion being born, because it shows that it actually may have flirted with compromise but then rejected it, and, when in triumph, it was pretty merciful." Rushdie wrote about the nature of a divine revelation to a common man, which is course of time becomes religion to be followed. Rushdie, through the fictionalization of the historical and religious events, tries to show how the idea of religion and even its origin have been influenced by the political factors and other forms of compromises. In his early years in Cambridge, in the year 1967, he wrote about ' Muhammad, the Rise of Islam and the Early Caliphate', which was not just his father's dream come true but "analytically, judiciously, properly"(40, Joseph Anton) studied the life of the Prophet and the birth of the religion as events inside history. Rushdie's prophet inside the novel was not Muhammad who once lived in the city of Mecca. Rushdie treated him as a man not as a divine figure. The Satanic verses showed prophet as "a man of his time, shaped by that time, and, as a leader, both subject to temptation and capable of overcoming it" (74, Jospeh Anton). Rushdie's prophet appeared just in the dreams of a man who is going crazy due to loss of faith. Rushdie's opponents call it concealment however. To his foes, his sin is hidden behind his fiction. Before Iran issued fatwa against Rushdie, the few Iranian booksellers who sold English language books assumed that it won't be problematic to sell Satanic Verses as Rushdie's previous book Shame which had gain the approval of Mullahs. Copies of Satanic Verses were imported and they remained on sale for six months from the book's first publication in September 1988. There wasn't any opposition against the sale until the fatwa of February 1989. On Wednesday 17 February, the book left Rushdie's desk and Rushdie himself has written that:

When a book leaves its author's desk it changes...it is irretrievably altered...that no longer belongs to its author. It has acquired, in a sense, free will. It will make its journey through the world and there is no longer anything the author can do about it. The book has gone out into the world and the world has remade it. The Satanic verses had left home. Its metamorphosis, its transformation by its engagement with the world beyond the author's desk, would be unusually extreme (90-91).

Here, Rushdie hints at reader-response theory, which says readers are free to interpret text in their own way though such hinting is not beneficial in his case. Khomeini interpreted his text in Islamic light and accused him of being against Islam, Prophet 
and the Quran. Rushdie and his supporters may take the stance of freedom of expression and the aesthetics engagement of the ethics, which devotees of Khomeini are condemning on the grounds of extremism and fundamentalism. Still the question of morality subsists. The predicament of morality has not been resolved. Does Rushdie hold modern/ postmodern morality? and Khomeini holds Islamic/ religious morality?

In Among The Believer, Nobel laureate V.S.Naipaul, while investigating the reason behind the fundamentalist zeal that hypnotized the youth in Iran and other Muslim states, writes about Khomeini as:

Fully disclosed, the Ayatollah had turned out to be nothing less than the interpreter, for Iranians, of God's will. By his emergence he annulled, or made trivial, all previous protests about the fascism of the Shah (11).

Naipaul had visited Iran soon after the revolution and he finds that the Islamic revolution which took place under the leadership of Khomeini had taken wicked turn by executing prostitutes, brothel keepers, by outlawing music, by reinforcing Islamic rules about women and by separating the sexes. Some days after Naipaul arrived In Tehran, Khomeini had said on the radio that:

I must tell you that during the previous dictatorial regime strikes and sit-ins pleased God. But now, when the government is a Muslim and a national one, the enemy is busy plotting against us. And therefore staging strikes and sit-ins is religiously forbidden because they are against the principles of Islam (11). The rationale behind Khomeini decision to issue a death threat to citizen of another country can be understood from the aforementioned statement of Khomeini and his adherence to Islam and its principles, which with the almost "unapproachable intricacies of their faith is based on revelation within revelation and divergence within divergence"(21). His observance to Islam was such that he imposed Islamic bans on alcohol, western television programmes, fashion, music, mixed bathing, women's sports, dancing, among others.

In the case of Nasrin, Bangladesh Government took side with the religious extremists against her and banned all of her books in Bangladesh. The opponents of Nasrin---can be deemed as the "Bangladeshi Iranians," as Rushdie correctly says in his letter to Nasrin, who is ridiculed as "the female Salman Rushdie" by her opponents. Muslim leaders issued fatwa against her for stating that the Koran should be revised to get rid of its ambiguities about the rights of women, and also for having written the book Lajja where she has displayed the suffering of minority Hindu family. Once Nasrin said in an interview, "I write against Islam and sharia law. Our government uses Islam in their politics because of the vote, so they are against me". Her novel Lajja, banned in her home country, became a best seller in neighboring India. In an interview to an Indian newspaper, The Statesman, she said that she is not in favor of minor changes in Koran. 
What provoked the Islamic religious establishment against her with wrath was when she was heard saying that the Koran should be revised thoroughly. The central belief of Islam is that Koran is compilation of God's words and those penned words cannot be altered.

To discuss the issue of apostasy would be of help here. In Freedom of Religion, Apostasy and Islam, Abdullah Saeed and Hassan Saeed while reviewing the debate on apostasy in Muslim history, conjure up the issue of hostility between apostasy laws and the freedom of belief. Apostate--a disloyal person who deserts his religion-- or apostasy laws were purely internal issue until Khomeini from Iran issued fatwa to Salman Rushdie living in London, and called the latter an apostate. Ahmed Subhy Mansour writing a review to Freedom of Religion, Apostasy and Islam in The Middle East Quarterly writes: "Muslim intellectuals accused of apostasy in Egypt alone include Farag Fuda (murdered in 1992), Nagib Mahfouz (stabbed in the neck in 1994), Nasr Hamid Abu Zaid (ordered to divorce his wife in 1995), the feminist leader Nawal al Saadawy, who has received death threats - and this author (Mansour) who was fired from his position at Al-Azhar University in 1987 and briefly jailed". In the Thirteen Chapter of the book, Abdullah Saeed and Hassan Saeed argue that the reaffirmation of pre-modern Islamic law of apostasy (riddah) developed for different reasons is unfavorable in the modern period and they finally call for an idea of religious freedom within Islam in line with modern realities. While discussing about freedom, or more precisely artistic freedom, the response of the United States-based publishers and intellectuals to fatwa and condemnations, and burning of The Satanic Verses is worth to mention. On 22 February 1989, the day when the novel was published in America, The New York Times carried out a full-page advertisement by the Association of American Publishers, the American Booksellers' Association and the American Library Association, which said, as Rushdie mentioned in his memoir as:

Free people publish books. Free people sell books. Free people buy books. Free people read books. In the spirit of America's commitment to free expression we inform the public that this book will be available to readers at bookshops and libraries throughout the country. PEN American Centre, passionately led by his beloved friend Susan Sontag, held readings from the novel. Sontag, Don DeLillo, Norman Mailer, Claire Bloom and Larry McMurtry were among the readers (150). Only free society could understand the importance of aesthetic freedom.

At a time when attacks on artistic freedom were being multiplied in different corners of the world including England, Iran, Pakistan, India, and some parts of Africa. Despite India's much-proclaimed secularism, Indian government had banned Satanic Verses in the October of 1988. The book was banned not by any authorized body but it came from the Finance Ministry, which under the Section II of the Customs Act, prevented the book from being imported. 
Once, the first prime minister of independent India, Jawaharlal Nehru had said that the authority to determine what shall be read and what shall not be, is always dangerous. Nehru probably had hinted at the censorship of books by the then British Raj, "but these words could be still used, almost sixty years later, as a critique of India itself (Joseph Anton, 117). The South African government had banned The Satanic Verses disparaging it as a "work thinly disguised as a piece of literature...disgusting not only to Muslims but to any reader who holds clear values of decency and culture "(121). But, South African writer Paul Trewhela "defended The Satanic Verses as belonging to the anti-religious literary tradition of Boccaccio, Chaucer, Rebelais, Aretino, and Balzac, and argued for a robust secularist response to the religious attack"(124). In most of the Islamic societies including Iran and Pakistan, The Satanic Verses, according to Rushdie is being used as a football in a political game. In Pakistan, destabilizing the then Prime Minister Benazir Bhutto's administration had been the demonstrators' real aim (134). While the wars of ideology and culture (the culture of central Europe was asserting itself against Russianness to unmake the Soviet Union) were moving to the centre of the stage. And his novel, unfortunately for him, would become a battlefield (110).He hoped and he often felt he needed a more particular defense, like the quality defense made in the case of other assaulted books, Lady Chatterley's Lover, Ulysses, Lolita, because this was a violent assault not on the novel in general or no free speech per se, but on a particular accumulation of words and on the intentions and integrity and ability of the writer who had put those words together (115). The novel was denied its ordinary life and it became simply uglier, an insult. The book became insult and he the insulter not only for Muslims. Polls taken following rage against Rushdie showed that a large majority of the British public felt the writer should apologize. He did apologies, which was however rejected, and then half accepted, and then rejected again, both by British Muslims and by the Iranian leadership. The statement that the writer of The Satanic Verses made was one he had actually loathed. He stated:

As author of The Satanic Verses I recognize that Muslims in many parts of the world are genuinely distressed by the publication of my novel, I profoundly regret the distress that publication has occasioned to the sincere followers of Islam. Living as we do in a world of many faiths this experience has served to remind us that we must all be conscious of the sensibilities of others (145). Rushdie's that he was apologizing for the

mess and misery, which he had never wanted to happen. Most importantly, he wasn't apologizing for the book itself. He was fully aware of other's sensibilities, which for him however, doesn't mean that he should surrender. That was his "combative unstated subtext"(145) despite various threats from Islamic communities. "A black arrow of retribution is flying towards the heart of that blasphemous bastard," Khamenei said during a visit to Yugoslavia. An Iranian ayatollah named Hassen Sanei offered \$ 1 million in bounty money for the apostate's head. Rushdie says in his memoir that "it was not clear if this ayathollah possessed \$1 million”(148). 
A Muslim fanatic political leader of Bangladesh also issued a bounty of $\$ 2,500$ for Taslima Narsin's death after the government banned her book Lajja and her feminist views were sternly attacked by Islamic radicals as impious. One of the columns of the Opinion page of New York Times, published a writing with a title "Censorship by Death" on July 6, 1994 described the Narsin's case as: "A 31-year-old writer named Taslima Nasrin has been given until Aug. 4 by a court in Bangladesh to come out of hiding and face arrest on charges of insulting Islam in a newspaper interview. If she does show up, she risks being killed. A Muslim fundamentalist political leader has offered $\$ 2,500$ for her death; snake charmers threaten to release 10,000 venomous cobras unless she is hanged."

The New York Times also stated that the bounty was inspired by the fatwa issued to Rushdie, and not only called for preservation of religious values through mutual tolerance but also commented on the attitude of Bangladesh government as shameful display of intolerance. The New York Times said: “The price on Ms. Nasrin's head was obviously inspired by the bounty offered by Iranian mullahs for the death of Salman Rushdie, whose novel The Satanic Verses was also assailed as blasphemous. It cannot be said too often: The true blasphemy is to kill, or threaten to kill, anybody for writing a book. Religions are not threatened but protected by mutual tolerance, a lesson the West has learned at bitter cost from inquisitions and witch-burnings. So the fever spreads, turning countries like Bangladesh, whose Muslim leaders once talked of secularism and tolerance, into republics of silence. Norway has laudably offered to mediate a safe-conduct exit for Taslima Nasrin. Meanwhile, to her persecutors, including a Government that has surrendered to extremists, one word suffices: Shame." Narsin has been prevented by authorities to go back to her country since 1994 and is obliged to take refuge in other countries. Rushdie cannot go back to his birthplace, Bombay in India, due to death threats. Rushdie is living his life in hiding. The Japanese translator of The Satanic Verses was assassinated. The Italian translator was stabbed, while Norwegian publisher was shot. The towering figure of Indian painting, MaqboolFida Husain, was hounded into exile in Dubai and London, where he died, because he painted the Hindu goddess Saraswati in the nude. They were demanding their rights to freedom of expression and thought, but with little public support, they have been condemned as an apostate, confronting many calls for their execution.

Like the idea of morality in blasphemy, which has been discussed earlier, the notion of moral courage also shouldn't be dismissed. Social and political contexts in which arts are received have been always devoid of moral courage to withstand the different facade of reality. In the Opinion of the Sunday Review of The New York Times of April 27, 2013, Salman Rushdie wrote an article titled as "Whither Moral Courage," where he introduced us to the case of Saudi poet and journalist, Hamza Kashgari, who in the February of 2012 had composed three tweets about his individual understanding of Prophet as: "On your (Prophet) birthday, I will say that I have loved the rebel in you, that you've always been a source of inspiration to me, and that I do not like the 
halos of divinity around you. I shall not pray for you “.”'On your birthday, I find you wherever I turn. I will say that I have loved aspects of you, hated others, and could not understand many more". "On your birthday, I shall not bow to you. I shall not kiss your hand. Rather, I shall shake it as equals do, and smile at you as you smile at me. I shall speak to you as a friend, no more." Now, he has been condemned as an apostate, and is languishing in jail. Unlike the writers and intellectuals of the French Enlightenment, who dared to challenge the religious orthodoxies of their time and eventually created the modern concept of free thought, Kashgari, or even Rushdie and Narsin are hardly taken as intellectual heroes like Voltaire, Rousseau, and Diderot. The originality and independence of mind of the artists and intellectuals hardly derive respect, hindering ways to see World as a better place to live, sans bigotries and radicalism. We may respect the believers but it's not always necessary to respect the content of the belief. Why are people allowed to criticise political beliefs, but not religious beliefs?

Assorted opinions have caused a misunderstanding between ' hate speech' and ' freedom of speech' and who is the authority to draw line between what is free speech and what is hate speech. It varies from cultures to cultures and religions to religions. What some may consider hate speech, while others may consider it as freedom of speech-- their right to express their opinions. Freedom of expression is safeguarded by all major international human rights instruments, including the Universal Declaration of Human Rights (1948), the European Convention on Human Rights (1950) and the International Covenant on Civil and Political Rights (1966). Freedom of expression is essential for a democratic society, and the idea of freedom of expression is applicable not only to 'information' or 'ideas' but also to those that offend, or shock the State or any other human institutions. Paul Marshal, a senior fellow at the Hudson Institute's Center for Religious Freedom delivered a lecture on the issue of blasphemy and free speech at Hillsdale College's Allan P. Kirby, Jr. Center for Constitutional Studies and Citizenship in Washington, D.C., on February 3, 2012, where he said that mounting threats to freedom of speech in the name of preventing insults to religion, will revive blasphemy laws. He said: "a growing threat to our freedom of speech is the attempt to stifle religious discussion in the name of preventing 'defamation of' or 'insults to' religion, especially Islam. Resulting restrictions represent, in effect, a revival of blasphemy laws". Mostly blasphemy laws in Muslim countries are channeled by governments for political purposes. In September 2005, the Danish cartoons of Mohammad were reproduced by newspapers in Muslim countries. There was no immediate violent response from Muslim radicals. Violence only erupted after an Islamic conference was held in December 2005 in Saudi Arabia, urged its member states to oppose the cartoon. In February 2006, five months after the cartoons were published, Muslims across Africa, Middle east, Asia staged violent demonstrations, killing over 200 people. Saudi Arabia and Egypt warned to boycott Danish products. Iran and Syria manipulated riots while for Turkey, the cartoons became bargaining chips in negotiating with the U.S. over appointments to NATO. 
In Islam, blasphemy laws have also been imposed to repress the minorities. In Saudi Arabia Shiites, especially Ismailis are repressed. Iran represses Sunnis and Sufis. In Egypt, Shia leaders have been tortured.In Afghanistan, the editor of Haqooq-i-Zen magazine, and a shia scholar Ali Mohaqeq Nasab was tortured and imprisoned when he condemned stoning-- the punishment for adultry in radical Islamic communities, and for penning ' un-Islamic' articles. Bangladesh imprisoned Salahuddin Choudhury for hurting "religious feelings" after the latter advocated for peaceful relations with Israel. In Iran, Ayatollah Boroujerdi was jailed for arguing that "political leadership by clergy" was contrary to Islam and cleric Mohsen Kadivar was imprisoned for "publishing untruths and disturbing public minds" after writing Theories of the State in Shiite Jurisprudence, which questioned the legal basis of Ayatollah Khomeini's regime. Saudi Arabia imprisoned the democracy activists Ali al-Demaini, Matruk alFaleh and Abdullah al-Hamed for advocating "democracy" and "human rights," calling for a written statute. Saudi teacher Mohammed al-Harbi was sentenced to 40 months in jail and 750 lashes for discussing the idea of Bible inside the class and making proJewish remarks.

Taking these cases into consideration, besides that of Rushdie and Narsin, it seems reforms and free speech in radical Islamic societies are not easily endured and appreciated. Owing to the same situation, western governments have called for the control on the speech regarding Islam. In 2009, Yale University Press got rid of all illustrations of Mohammad from its book by Jytte Klausen on the Danish cartoon crisis. It also removed Gustave Doré's 19th-century illustration of Mohammad in hell. Random House rejected a novel about Mohammed's wife, Jewel of Medina, written by American writer Sherry Jones. They rejected at the last minute, to protect "the safety of the author, employees of Random House, booksellers and anyone else who would be involved in distribution and sale of the novel." The comedy show South Park refused to show an image of Mohammed in a bear suit, even though it mocked other religious figures from different religion. Even President Obama cautioned the world to shape speech about Islam, in his Cairo speech in 2009. He said he has a responsibility to combat negative stereotypes of Islam whenever they appear.

Blasphemy laws not only threaten free speech and the free exchange of ideas but also destroy social peace and harmony. To exemplify, Norway's restriction on hatespeech hadn't prevented Anders Behring Breivik from murdering over 70 people not only because of his antipathy to Islam but as his writings suggested, he couldn't be heard otherwise. Nasr Abu-Zayd, a Muslim scholar who was driven out of Egypt said: "Charges of apostasy and blasphemy are key weapons in the fundamentalists' arsenal, strategically employed to prevent reform of Muslim societies, and instead confine the world's Muslim population to a bleak, colorless prison of socio-cultural and political conformity". As the late Abdurrahman Wahid, former president of Indonesia, the world's largest Muslim country, and head of Nahdlatul Ulama, the world's largest Muslim organization, wrote in his foreword to Silenced, blasphemy laws "... narrow 
the bounds of acceptable discourse. . . not only about religion, but also about vast spheres of life, literature, science, and culture in general. . . . only encourage Muslim fundamentalists in their efforts to impose a spiritually void, harsh, and monolithic understanding of Islam upon all the world. . .(3). Ulama believes that blasphemy laws tarnish the so-called sacredness of the religion and has never been beneficial to life, liberty, free thoughts, literature, science and culture. Penal codes against desecration of sacred symbols or holy ideas would only incite the fanatics and fundamentalists, most of the time even misrepresenting and misinterpreting free speech as the hate speech.

\section{Conclusion}

To end the classical tension between faith and free thought, and at least to terminate the clash between secular libertarians and the believers, a contextualized approach could be adopted to critically scrutinize, whether the concerned speech is hate speech or free speech. Such contextualized consideration would of course minimize the cases of blasphemy and promote freedom of expression, degree of tolerance, along with the rational investigation of the preternatural admixture of secular and religious values. Nasrin's case, brushing off for a while the common heritage of blasphemy she shares with Rushdie, in regard to the thematic concerns of her work, Lajja is based on an unfortunate incident of communal violence imposed by Bangladeshi Muslims against Hindus, and its malevolent effects, following the demolition of a Babri Mosque by Hindu fanatics in India, while Rushdie, as he has often claimed in public and press and in his memoirs and essays, The Satanic Verses is phantasmagorical understanding of the nature of revelation to a schizoid. The appearance of a meta- fictional character who shares his linguistic identity and still some historical identities with Prophet Mohammad (in fiction Mahound) in a book replete with mystic vision, hallucinations, could incite only fanatic, rabid believers, and irrational enthusiasts, while, in grips of uncompromising ideologies, issue fatwas and death sentences. The Satanic Verses doesn't mean that The Quran is inspired by Satan. Firstly, The Satanic Verses is a work of fiction. A novel. Secondly, the controversial section appears in one of the schizophrenic character's dream. Thirdly, all the religions, clerics, and disciples need to show up the real courage to tolerate all sorts of debates, as Islam has since its inception. After all Blasphemy is outdated souvenir of the pre-enlightenment times. Any persecution against matter of faith and individual belief is inappropriate, as the unflinching belief is in itself the armor against blasphemy prosecutions. Even though the crime of blasphemy has now been abolished, some of the British Commonwealth nations including Pakistan, Bangladesh, and Iran still provide room for the wretched legacy, butchering the idea of free speech at birth. The world would be a better place to live learn, and serve if we make critical, creative and philosophical interventions to wipe out such puritanical medieval mannerism as the combat against witchery has been significantly successful to end the violence of men against men. 


\section{References}

Fisher, Anthony., and Hayden Ramsay. "Of Art and Blasphemy." Ethical Theory and Moral Practice, Vol 3. No.2 (Jun 2002): pp 137-16. Springer. Online .

Foucault, Michel. "Truth and Power." Ed. Critical Theory Since Plato. Hazard Adams and Leroy Searle. Thomson, 2005. Print.

Gorky, Maksim. On Literature. University of Washington Press, 1973. Print.

Gosh, Amitav. "The Ghosts of Mrs Gandhi." Incendiary Circumstances: A Chronicle of the Turmoil of Our Times. Houghton Mifflin Company, 2005. Print.

Laeuchli, Samuel. Religion and Art in Conflict. Philadelphia: Fortress Press, 1980. Print.

Levy, Leonard. Treason Against God: A History of the Offense Against Blasphemy. New York: Schocken, 1981. Print.

Longinus. "On the Sublime." Ed. Critical Theory Since Plato. Hazard Adams and Leroy Searle. Thomson, 2005. Print.

Mansour, Ahmed Subhy. "Review to Freedom of Religion, Apostasy and Islam." The Middle East Quarterly. Vol Xii. No 4( Fall 2005). Online .

Naipaul, V.S. Among the Believers. London: Pan Macmillian Ltd, 2003. Print.

Nasrin, Taslima. Lajja. New Delhi: Penguin Books India, 1994. Print.

Plekhnov, G.V. Art and Social life. Bombay:Peoples Publishing House, 1953. Print.

Reynolds, Henry. "Mythomystes." Ed. Critical Theory Since Plato. Hazard Adams and Leroy Searle. Thomson, 2005. Print.

Rushdie, Salman. Interview by Steve Inskeep. NRP. 18 September. 2012. Online.

- - - . Joseph Anton: A Memoir. London: Jonathan Cape, 2012. Print.

- - - Joseph Anton: A Memoir. London: Jonathan Cape, 2012. Print.

Russell, Bertrand. The Analysis of Mind. London: George Allen\& Unwin Ltd. Print.

Sartre, Jean Paul. "For Whom Does One Write?" What is Literature?Routledge Classics, London, 1967. Print.

The Magic of Belle Isle. Dir. Rob Reiner.Perf. Morgan Freeman, Virginia Madsen, Emma Fuhrmann, Madeline Carroll.2012. Film. Video.

Tsetung, Mao. On Art and Literature. Foreign Language Press, 1960.Print.

Webster, Richard. A Brief History of Blasphemy. Southwold: The Orwell Press, 1990. Print.

9006 